\title{
Synaptic spaces of Europe: A challenge for spatial planning
}

\section{Cecilia Scoppetta}

Sapienza University, Rome, Italy

\section{Email address:}

ceci62@libero.it

\section{To cite this article:}

Cecilia Scoppetta. Synaptic Spaces of Europe: A Challenge for Spatial Planning. Social Sciences. Special Issue: Geographical evidence in changing Europe. Vol. 3, No. 4-1, 2014, pp. 46-56. doi: 10.11648/j.ss.s.2014030401.15

\begin{abstract}
On the background of contemporary rescaling process and of the current broad rethinking of some relevant concepts - such as "region", "territory", "locality", and "space" - the case of the Baltic Sea Macro-Region, and of the related place-based EU successful «experimentalist» strategies highlights the emerging of «soft spaces» as new forms of territorial organisations. These clearly appear as a result of EU "soft" ("lateral") territorial approach outlining a really innovative multileveled spatial pattern. By using a biological metaphor these soft spaces may be intended as «synaptic spaces» clearly claiming for a radical shift in planning approaches, by moving towards soft and synaptic planning practices involving «'soft process' of negotiation and learning». Features of these spatial configurations drawing new continental geographies are explored by highlighting the role both of images/imaginaries and historical/geographical/cultural roots, to be used (re-interpreted) in the de-construction/re-construction of the contemporary European spatiality. In this sense, we may say that, according to Faludi «geography still matters» (and also history!). In fact, Baltic Sea cooperative networks (that is: the basis of the new EU strategy) can be seen as a return to what once was an important communication channel for thousand of years and flourishing trade in the region. The model is that of the Hanse League, based on flexible not hierarchical (mainly economic) «weak ties» - or «loose coupling» - among autonomous cities (but not exclusively), which share a transnational unbounded Hanseatic "space" (not "territory") and which are periodically (not always) able to act as a collective actor to achieve local collective competition goods avoiding the «trap of joint decision». It remains to be seen whether such a strategy - which has proved successful in the Baltic area - will be so effectively applied to other specific spatial and cultural contexts (with their differences in challenges and potentials), such as the Danube corridor, or to the much more "explosive" Mediterranean basin.
\end{abstract}

Keywords: Spatial-Political Rescaling, EU Macro-Regional Strategies, Images, Networks

\section{Introduction: on Contemporary Rescaling Processes}

Since the end of the 70s, many scholars have focused on the emerging of metropolitan regions as dominant economic units in global society (Storper, 1997; Sassen, 2001; Scott, 2001) and as a key level supplanting national/regional/local governments as the place of decision-making (Altshuler et al., 1999; Katz, 2000). Some of them have linked the rise of these entities to the shift from government to governance (March \& Olsen, 1995), within which network forms are transforming, supplanting, or supplementing historical structures such as markets and hierarchies (Castells, 1996). Three main (often interrelated) paths have been explored: one is networking, encompassing processes and flows, actors and interest, organisations and structures, ideas and capitals. The second is governance, also claiming to engage a wider range of sectors and interests in governing, and the third is the scale of governance.

Governance research has pointed to the importance of processes of de-territorialisation and re-territorialisation in re-defining governmental boundaries and jurisdictional competences. Network analysis has inquired into emergent forms of interest intermediation that exceed or bypass established institution of territorial representation. Both emphasize the relativisation of geographical space - in particular of bounded space - as a determinant for policy action; both share an interest for phenomena of re-scaling of State action and for shifts in the meaning of territoriality for public policies. 
Research traditions associated with scale (or scaling) intended as the identification of the proper placement of governing responsibility - have a somewhat longer history than governance or network traditions. Antecedents include coordination among levels of government (Hambleton, 2003; Dijst et al., 2002), decentralisation from higher to lower levels, devolution of functions among levels, and subsidiarity, which attempts to locate functions at the most appropriate level. But now there is something new: urban and regional studies have recently experienced a reassessment of geographical notions - such as "region", "territory" and "locality" - in face of emergent sociospatial phenomena that highlight an innovative concept of spatiality. In this sense, spatial re-scaling maybe represents one of the most significant contemporary changes in territorial interpretation and (consequently) planning.

Critical geographical studies have identified four geographical dimensions as co-constitutive of sociospatiality: place, territory, scale and network. Among these, territory and territoriality entails the enclosure, bordering and fragmentation of social relations. Once established, these bounded territories constitute a «fixed, stable and immobile grid» and an «element of fixity on an otherwise changing geographical landscape» (Brenner, 2009), which it is difficult to modify.

Scale and scaling entails the vertical differentiation of social relations among, for example, global/State/regional/urban/local levels, as it is the assignment of responsibilities and the social construction of capacities of institutions (Miller, 2009): «the focal setting at which spatial boundaries are defined for a specific social claim, activity or behaviour» (Keil \& Mahon, 2009). In this sense, scale-shifting refers to changing relationships, sets of participants, resources involved. Both scaling-up and scaling-down can produce a more favourable political opportunity structure for particular interests. Scale-shifting (or scale-jumping) also relates to the existence of extralocal and inter-scalar rules regimes that «constrain and channel the strategic options and tactical behaviour of local actors» (Miller, 2009): higher level institutions establish/limit the scope for policy and actions at lower levels, enabling/preventing democratically-made decisions. In this sense, besides shifting responsibilities and capacities between levels of government, re-scaling also can involve the invention of new scale of actions: «scale is the actor's own achievement»(Keil \& Mahon, 2009), because «we scale politics to our own purposes» (Magnusson, 2009).

But rescaling does not only mean the shift of responsibilities from one level to another: it also implies the emerging of multi-scalar interactions and of «a governance environment characterized by multiple constellations and multiple coalitions for development that define a geography of governance that is flexible, often overlapping, and increasingly autonomous from given territorial jurisdictions» (Gualini \& Woltjer, 2004). This approach goes beyond rescaling in recent theoretical literature (Brenner 2003; Salet, 2003). By following part of the logic inherent in its predecessors (coordination, decentralisation, devolution, and subsidiarity) aimed at responding to the breakdown of hierarchy, a principle behind rescaling was to find the most appropriate scale of governance for policy delivery. The evolution of terminology reflects two substantive facts. The first is the evolution of thought regarding institutional design and policy, which has recognized that hierarchical bureaucracies, command and control are not as effective in a flexible global economy and democratic institutions. The second is the emerging of governance alongside government.

But the main innovative feature of multi-scalar large institutional networks seems to be their learning dimension: they evolve and learn through complex processes in ways that are distinct from the ways that "mere" organisations or individual institutions. Grasping this peculiar way is essential to understand how they function/malfunction, how they create, decide on, and execute policies, strategies and plans, and how they exert power and influence to obtain outcomes, and how, in turn, they are affected by power and influence of their own members and by those outside them.

\section{European Soft Synaptic Spaces}

The interest on territorial changes due to globalisation has inevitably led to a broad rediscovery of the spatial in policy disciplines (Le Galès, 1998; Salet \& Faludi, 2000): the linkages among these emergent concepts - territory, governance, networking, rescaling - have been deeply investigated (Castells, 2001; Scott, 2001; World Bank, 2003) and spatial planning has become a fertile field for this analysis (Vigar et al., 2000; Albrechts et al., 2001; Salet et al., 2003).

Undoubtedly, the Europeanisation process has highly contributed to this renewed interest. Reasons are firstly to be researched in the fact that European space - a borderless single market within which internal space mobility coexists with national territories. But EU can no longer simply be viewed as a Europe of nation-states or a putative supra-state: it can rather be conceptualised - and this is its spatial novelty - as a multileveled or networked space of governance.

Further reasons can be find in the fact that, even if Brussels had never been granted a specific competence, interest in territorial issues are related to EU regional policy since the mid-70s, as it was conceived to balance development disparities between countries focusing on the spatial impact of regional development within the framework of the Structural Funds and the objective of social cohesion. And, undoubtedly, both agricultural and regional policies (that is: the most of the European budget) presents striking territorial effects. In addition, during the ' 90 s, EU policies started focusing on the role of cities as growth engine, in the light of the need of competitiveness to face the changes due to globalisation. Cremaschi (2004) highlights four different tiers of the «wedding cake» of EU 
spatial policies: the basis of this "cake" consists of regional policies, the second tier is infrastructure networks and trans-European cooperation, the third is urban initiatives and the last - according to an idea originated in the Council of Europe as early as 1964 - corresponds to a spatial development perspective, that is a policy document aimed at guiding integrated strategies of territorial planning of member states. Cremaschi (2004) also underlines a somewhat double character of the concept of spatial development, a neologism which «combines the German practice of regulatory planning of physical and environmental factors with the British concern for local economic development».

Thus, the European spatial logic has led to a sort of "light" Europeanisation, which clearly refers to the three relevant contemporary issues of networking, governance and rescaling. In this sense, the spatial novelty of this soft and "lateral" approach can be clearly observed in the multifold terms and concepts that are used in EU territorial policies, since they have at the same time both a physical and not physical meaning. The term "polycentrism" (Davoudi, 2003) is the main example, because it refers to physical features, such as a multiple centres and diffused growth rather than core-periphery distinctions, but it is also connected with the idea of multi-level governance, which implies (not physical) partnerships between EU institutions/national governments/regional/local authorities. It is easy understanding why this flexible notion of polycentrism - which refers to forms of non-territorial politics which emanate from a multiplicity of (physical) sites and which cannot be reduced to a single centre - has become a useful way of thinking about the decentred, deterritorialized (and re-territorialized) dynamic nature of Europe, since this term has a much wider applicability to political and societal transformations under conditions of globalization (Scholte, 2004; Delanty \& Rumford, 2006). Another useful neologism is "territorial cohesion" that link together both spatial and economic dimension.

This means that the «governance turn» in European studies (Marks et al., 1996; Jachtenfuchs \& Kohler-Koch, 2004; Bache \& Flinders, 2005) corresponds to a «spatial turn» (Berezin, 2003) because of the transformation of involved spaces. In fact, rather than being primarily concerned with state-building or the institutionalisation of governance structures, the EU is centrally concerned with the construction of European space(s), and with the ways of understanding them, that is: a result of processes by which these governance spaces are constructed, showing the way space itself is constitutive of social and political relations.

These particular features of the (still ongoing) EU construction, on the background of the contemporary spatial re-scaling, have led to the emergence of the socalled "soft spaces" (Waterhout, 2009; Faludi, 2010b; Haughton et al., 2010): multi-area sub-regions in which regional strategies are being made between or alongside formal institutions and processes. These spaces are often overlapping and characterised by fuzzy geographical boundaries. In a certain sense, we could also talk about "synaptic spaces", whose spatial dimension constantly changes as it is given by the lighting up and turning off of inter-relationships involving not only action potential, but also knowledge as a further learning value towards a coevolution of places and planning approaches and styles (Faludi, 2008). Developing a new imagination of spatial phenomena may enable re-assessing their socio-political features, challenges and potentials. In fact, this innovative spatial concept means re-interpreting space as an open and dynamic multiplicity of relations through which power is being constantly re-shaped. This implies changes in powers across the existing tiers of decision-making, original scales of intervention, new actor constellations, and variable geometries of governance. According to Waterhout (2009) and Faludi (2010b) these emerging "soft spaces" seem to require a concept of soft rather than hard planning (for soft rather than hard spaces) to be used wherever challenges cut across boundaries demanding innovative joint action.

\section{Using a Biological Metaphor to Define the Main Features of Synaptic Planning Approaches}

A fascinating suggestion is given by studies on selforganisation in the research field of biology and, more generally, on the topic of complexity and of artificial intelligence (Morin, 1983; Prigogine \& Stengers, 1979, Anderson, 1999; Kauffman, 1995).

As it is known, the biological evolution implies that microscopic components, characterised by a simply structure and strong and relatively rigid ties, constitute through their interaction - the constructive elements of more complex systems with weaker and more flexible ties, which allow the adaptation to unpredictable environmental changes. This highlights the relevance of resilience rather than stability: the latter is what allows a system to quickly come back to its original status after a temporary perturbation; differently, resilience allows a system to adapt itself to perturbations, especially if these are deeply different from those it already knows, and to absorb unforeseen shocks, continually adapting and evolving so as to resist collapse. In fact, the concept of resilience is defined as the «measure of persistence of systems and their ability to absorb change and disturbance and still maintain the same relationships between population or state variables» (Holling, 1973). In other words, a resilient system is formed by the dynamic interplay between deterministic forces and random events, structural factors and human agency, linear paths and contingency.

The example is the self-organisation of living organisms (Bak, 1996): they are not a kind of automaton, directed from outside by a deterministic program, but systems whose state lies between the two extremes of a rigid, immovable order - which cannot change without being destroyed, as the order of crystals is - and a constant 
renewal without any stability. This state is clearly not static, but it allows reacting to random perturbations (Waldrop, 1992). In this way, transformations are not simple destructions of the already existing, but re-organisations enabling the emergence of new features, which can be a new structure or a new behaviour influenced by new structures (Holland, 1995). Every combination and renewal of a single part implies a different functional organisation, that is: a different meaning of the relationships established among different parts. Therefore, the most relevant aspect of self-organisation is the sense of self-creation (Atlan, 1983).

This means that the self-organisation of a system can be conceived as a «not banal machine» (van Foerster, 1981), which - differently from a "banal" one - does not work with a predictable input/output logic, by simply responding to the specific need for which it has been constructed. This is because a "not banal" machine is characterised by its own internal status that can generate multiple outputs.

A further feature of self-organisation of living organisms obviously is its complexity: biological systems, in fact, are at the same time something more and something less than the simple sum of their parts. This allows the emerging of features deriving from accidental consequences and secondary products of interaction, and these, in turn, through a feedback mechanism, stimulate each single part of the system towards the expression of their specific potentialities. An example is given by the way in which culture or language - that is: features that exist at the level of the system as a whole - retroactively work onto the single components, by allowing the development of potentialities of each individuality. In fact, as well as spatial studies, contemporary sciences of complexity are marked by a crisis of traditional "boundaries": between concepts such as "producer" and "product", "cause" and "effect", "one" and "many", "organism" and "environment" (and also between "science" and "not science"). This leads to the concept of «recursive organisation» (Morin, 1977), in which effects and products are conceived in turn as necessary for the production itself.

Transferring the biological metaphor within the planning sphere means considering soft synaptic spaces as a collective construct, because they cannot be ascribed to a single definitive and deterministic project: in fact, the different actors involved constantly interpret it, take decision and act. This collective construct is a resilient experimental network based on weak ties shaping a not always predictable spatiality. But, in a certain sense, the byproducts of this construct - the learning process given by the feedback mechanism - seem to be more relevant than the product itself, because they may allow further developments. As a "not banal" machine, the construct of a synaptic space is featured by its own internal status - and this means that it depends on history - but it is able to produce multiple outputs and different development trajectory.

\section{The Baltic Sea EU Macro-Region as a Synaptic Space}

A significant example of synaptic spaces conceived as a construct is given by the recently introduced concept of EU Macro Regions (Stead, 2011). Macro-regions mean regions comprised of adjacent territories from several different countries that share a number of common challenges. While there may be many such functional regions in Europe, especially connected with geographical features, it is the development of a Macro-Regional Strategy (MRS) that establishes a macro-region from the EU's perspective. For example, the EU MRS for the Baltic Sea Region published in the summer of 2009 and often presented as a blueprint for other possible macro-regions - is defined as «an integrated framework to address the challenges and opportunities of a particular geographical area» (CEC, 2009).

Even though the concept has been used in International relations before, and even though the collaborative work between national and regional actors in the Baltic Sea area has been quite extensive, this EU MRS brings something new and concrete on methods and actions for sustainable territorial development, as it is aimed at creating a joint "platform" to enable all partner to act together in a transnational context.

During the last twenty years a paradigm shift has taken place in the Baltic Sea Region, as cooperation in all levels has changed from earlier bilateral to multi-level transnational cooperation in networks, such as city or thematic networks, the VASAB Long Term Perspective and the EU project South Baltic Arc. Networks and cooperation patterns between the local authorities are an existing and well funded resource, but their full potential has not been utilised so far. The EU Baltic Sea MRS should serve as a pilot case and good example on how the EU addresses challenges related to a specific region, from a transnational and cross-sectoral perspective. Further examples of EU MRS include the recent Danube Basin Strategy, and those for the Mediterranean, Alpine and North Sea regions (under discussion/consideration).

The need for an EU MRS for the Baltic countries has largely arisen from the fact that eight of the Baltic countries became members of the EU with the major eastern enlargement in 2004. But we may say that since the end of the Cold War the development and integration of this region has expanded and deepened. Much of the activity and integration has happened within and between cities and local authorities thanks to cooperative networks - such as the Union of Baltic Cities, the Alliance of Baltic Cities, the Council of Baltic Sea States - as a return to what once was with the Baltic Sea as an important communication channel for thousands of years and flourishing trade in the region.

An inclusive consultation process, aimed at identifying genuinely local concerns (and at building consensus from the bottom-up) constitutes the starting point of EU MRS. In the case of the Baltic Sea region, this process involved the 
submission of non-papers from governments and other official bodies, stakeholder events and a public consultation through the EU web site. This led to the establishment of three policy principles. The first is: no institutions or laws. In fact, before the establishment of the Baltic Sea EU MRS, a plethora of institutions already existed in this region (the Council of Baltic Sea States, the Helsinki Commission, the EU's Northern Dimension and the Nordic Council), but none of them took an integrated approach to coordinating all the sectoral policies. Nevertheless, it was felt that adding another administrative layer would not succeed in integrating this institutional network. Instead, it was decided to build the Baltic Sea MRS on existing institutions: notably the EU and, for cooperation with the external partners such as Russia or Norway, the Northern Dimension.

The second principle is: no new funds. In fact, it was felt that better coordination of the considerable existing resources - EU Structural Funds, research and IT EU programmes, Member State resources, funds from the EU Investment Bank and other international and regional financial institutions, such as the Nordic Investment Bank and the EU Bank for Reconstruction and Development was more important.

Thus, we have no policy instrument or planning programme in the original sense, because the Baltic Sea MRS is rather defined - and this is the third principle - as an action and place-based strategy with a functional spatial approach. Four main "priority areas" for cooperation have been identified (environmental sustainability, competitiveness and prosperity, accessibility and attractiveness, safety and security), and fifteen goals to convert them into concrete policy action. In addition, eighty "flagship projects" are distributed over the fifteen "actions", in order to implement them, and a number of "horizontal actions" (including urban, rural and maritime issues, territorial cohesion and spatial planning) cut across priority areas.

Although discussions have already begun on the question about whether a specific EU budget line can be allocated to macro-regions in the programming period beginning in 2014, the premises of no new funding, no new legislation and no new institution currently set the frame for a coordinating strategy of already existing resources, instruments and networks of different legal status and tiers: MRS's key-words are creative implementation and coordination between programmes. This means that the macro-regional approach is place-based, inclusive and multi-sectoral (while many of the actions need coordination of sectoral policies). It also is multi-instrumental - since the wide scope of actions makes it impossible to fund them solely through one instrument - and it is based on multiactor collaborations between different type of actors at various governance levels to reach consensus and to fine tune the actions. Thus, macro-regional approach requires imagination and lateral thinking rather than particular technical skills.

Another interesting novelty of MRS consists of its explicit experimentalism, since the EU Commission prepares periodical reports on the basis of coordinator reports and annual forums take place for partners and interested third parties, in order to review the strategy and to make recommendations on implementation.

But, in the light of the broader rescaling processes, the main relevant feature of MRS is related to the fact that the priorities do not necessarily have to be embraced by all actors, according to the principle of flexible membership: «the frontiers of a macro-region do not have to be precisely defined. Moreover, there is no requirement that any given territory be part of only one macro-region» (CEC, 2009). In fact, in the Baltic Sea region, some members focus on a select few, depending on their priorities and problems. This means that the physical boundaries of the target area may vary according to the relevance of the policy area in question: for some policies, all countries are involved; for others, policy might focus on a few regions, while some policies might be defined locally.

\section{Explorative Images towards a Shift in Planning Imaginary}

If different countries of a macro-region share a number of common challenges, it is possible hypothesising that the latter derive from a shared "image" of their territories, which in turn constitutes a powerful and communicative instrument of territorial knowledge allowing further unpredictable development.

In this sense, a shared image of the Baltic Sea region is undoubtedly given by the landscape of the Baltic Sea coast, characterised by the formation of flat beaches, called "haffs", which are almost completely separated from the open sea by a narrow ridge of land, the Nehrung (or "spit"). Such a narrow ridge of land is completely made up of shifting dunes, the securing of which is a constant problem for the population.

On the other hand, as macro-regions are proposed as a framework, we may say that also the latter is an "image" on the background of which all planning actions and policies can be oriented.

Generally speaking, on relationships between imagination (production/construction of images) and processes of knowledge a vast literature exists (Holton, 1978; Gruber, 1966; Kuhn, 1962; Starobinsky, 1970; Mills, 1959; Brown, 2003). The term "imagination" refers to activities of individual consciousness, through which each one, using images, represents to himself things, subjects or situations that, at that time, are not given to perception. Imagination can see elements concerning the problem and all significant relations between what it is known and what it is unknown, between what we know and what we want to know. Through imagination we put into inter-relation different knowledge so that they can be simultaneously used to interpret a situation. Imagination allows anticipating possible "scenarios" (frames) in which to place 
that problematic situation we are examining. Imagination, therefore, is not to be led back to "memory", by confusing "image" with "recollection", as a mere reproduction of sensitive things that are given to our mind through perception of senses: by recognizing its "creative" function, imagination is rather to be intended as «ability of possible» (Sartre, 1936, 1940). Within this perspective, "images" increase distance from "perception" and emerge with their own features. It leads to extend the term "representation" towards images that we recognize as "construction of the mind» (Jouvenel, 1964).

In fact, imagination first establishes a preference principle towards an idea, but also a different intensity among different representations, proposing an order between them. Furthermore, imagination allows transitions from an idea to another one through successive phases, by introducing to the mind simultaneous different representations and creating a convergence of many images within a single one (Kuhn, 1962).

Not by chance, a large sector of the vast bibliography on relationships between imagination and processes of knowledge regards "spatial" studies, both descriptive and operative, because of the use of representations (for example: cartographic representations) as main instrument. In the planning case imagination (production/construction of images) as interpretation (frame) means a way of analyzing, selecting, organizing and making sense of a complex reality, equipped with a spatial "appearance" (Rein \& Schön, 1986). Planners use representations as comprehensive "narrations" (reflecting how a society has been arrived to the present through the past) on which constructing an agreement for the future among different and often conflicting social groups, so defining a practicable «negotiation space» (Secchi, 1989).

But images may also play a role as suggestive guide of collective imaginary (in the sense of an interactive learning) or as exploration/evaluation (Palermo, 1998) of social availability towards some proposed solutions (Gabellini, 1996). Among those focusing on the meaning of representations as "projection towards the future" (visions), many studies emphasize the role of images within identity's (re)constructing processes. Anyway, the strategic meaning of images - in particular, of images which are produced within planning processes (scenarios) - has been largely acknowledged (Faludi 1996; Secchi 2000). In this sense, a scenario is an image of a possible desirable future (Hirschorn, 1980).

Differently from "images" - which are produced by individuals - "imaginary" is instead a dimension of history and society. As well as "imagination", "imaginary" refers to images, that is to an articulated set of persistent representations (Starobinsky, 1970), which are equipped with powerful inertia, by opposing to their replacement. But, on the other hand, imaginary is not featured as something stiffened, but rather as something that is subject to a constant evolution and enrichment (Gramsci, 1977). In this sense, imaginary is a category to be led back to a predominantly collective dimension, with a unifying role of subjects (that is: a community), which are recognizable also in relation to the set of images they share.

On the other hand, these shared images are connected to a set of values, "figures", norms and rules (Hobsbawm \& Ranger, 1987), cognitive and evaluative criteria, codes and languages, but also customs, beliefs, paradigms and «traditions» (Fleck, 1980), ritual practices, repetitions, frequent omissions and oversights (Soubeyran, 1988), "repertories", including what already exists (what is possible to describe and represent) and what, instead, does not exist yet (what is possible to imagine and prefigure). In a word, a system of relevant purposes through which a community recognizes what place within society it intend to hold in the future (that is: what is its own transformation project) and what it consider to have been in the past as well as the method of moral justification of its objectives.

Not only, therefore, each group (community) has its own imaginary (Baczko, 1978), but each recognizable level of a complex society refers to a specific imaginary (Patlagean, 1978). In this sense, it is possible to individuate some disciplinary imaginaries, that is: images (metaphors) which are shared by a scientific or academic community (Kuhn, 1962). It is also possible to individuate a "collective imaginary" based on the collective sharing of some particularly powerful metaphors (images): «perhaps universal history is the story of some metaphors» (Borges, 1963).

It is possible indeed to recognize some historical periods (Baczko, 1978) in which the broader collective imaginary appears as permeated by characters of one or more specific (disciplinary) imaginaries. In fact, boundaries among different imaginaries are not clearly defined, but fluid, discontinuous, sometimes overlapping and mutable over time (Bachelard, 1957) as well as the contribution of a certain specific imaginary to the construction of a larger collective one tends to change through stability/instability periods.

On the other hand, every specific disciplinary imaginary (for example: planning imaginary) has its own sedimentation and codification stages, and these could not always coincide with the pursuing transformations concretely acting in the realities (in "facts"). But this implies transferring them within the sphere of meanings (of collective imaginary). In this sense, it is possible to recognize reductions/expansion (Secchi, 1988) of "discursive" forms within «planning speech» (Secchi, 1984), which are associated with stability/instability periods. This means that the emerging of innovative "facts", characterizing instability periods, imposes the use of tentative (explorative) - necessarily indefinite, vague, often allusive - new categories (languages, images) towards the construction of innovative metaphors (utopias?).

Think of the different meanings that have been connected in different historical periods to the term "strategic planning" and to the need - in the mid-" 70 s and even more in the " $80 \mathrm{~s}$, after the interruption of growth 
conditions, which had been assumed as the norm - to develop new planning theories and methods to face the emerging problems, by "assimilating" the new explicit role of the market (together with its rationality, its jargon and its specific imaginary). And think also of the further evolution of the term in the ' 90 s that is: in the years of the rhetoric of competition among cities and territories and of the loss of authoritativeness of the old power and representation structures, demanding a wider inclusion of civil society in the sphere of planning. As a result, nowadays strategic spatial planning can be described as a social process through which local communities answer to endogenous and exogenous challenges connected to territorial governance (Healey, 1998; 2003a; 2003b).

In this sense, the concept of "synaptic spaces" may be conceived an explorative "image" towards a shift in planning imaginary.

\section{Geography (and History) still Matters: the Hanseatic Model}

Not by chance the firstly experimented macro-regional strategy is that of Baltic Sea. In fact, the model is that of the Hanse League, based on flexible not hierarchical (mainly economic) «weak ties» (Granovetter, 1983) - or «loose coupling» (Weick, 1976) - among autonomous cities (but not exclusively), which share a transnational unbounded "Hanseatic space" (not "territory") and which are periodically (not always) able to act as a collective actor to achieve local collective competition goods avoiding the «trap of joint decision» (Scharpf, 1986).

In fact, the Hanse was an economic system - and a cultural universe - in which cities were the basic nodules for interaction (Dollinger, 1964; D'Haenens, 1984; Schildhauer, 1988). It was never strictu senso a political entity or even a city league, but an economic association which - even if it sometimes exercised political or military functions - was made of units with different levels of alliance. Strong and stable political links proved evil for Hanseatic commerce, as it happened, for instance, when conflicts arose between the fur-providing Russians and the only prince who was also a member of the Hanse, the Great Master of the Teutonic Order (Schildhauer, 1988). On the contrary, looser and more mobile groupings seemed to work better.

The general assemblies, which usually took place in Lübeck, were the only durable institution of an organisation with no bureaucracy. While many minor towns were represented by the leading cities of their area, not even all the important cities were always present at the Hansetag, in spite of menaces and fines, so that it is difficult to know which cities belonged to the Hanse at a given time. The very way in which the Hanseatic cities grouped and the fact that some cities changed from one group to the other are also evidences of the laxitude of relationships within the Hanse. On the other hand, the Hanse surely produced a strong feeling of belonging far beyond commercial agreements. Even with so malleable organisation and with so fluid and de-territorialized external or inner limits, the Hanse of cities was, in the late Middle Age, a redoubtable economic and cultural power. At times, it gathered more than two hundred cities throughout a territory stretching over a thousand miles. These strongly interactive, decentralized but mutually coordinated small units developed a well-balanced urban self-organised system that survived for over three hundred years.

It is to be said that Marxist historiography has interpreted the Hanse as a colonial institution based on a class structure, which led to an economic domination against the preexistent populations and against the opposition movement coming from the small bourgeoisie and the working classes (Fritze, 1984). According to such an outlook, the Hanse considerably retarded the development of autochthonous middle classes among non-Germans, while maintaining for centuries a noticeable unbalance between economic centres and peripheries, only capable of providing raw materials. Such an interpretation has led - especially in the Countries "on the other side" during the Cold War (and especially in the DDR, but also, in a certain way, in the DBR, because of the collective mea culpa sentiment) - to assimilate the medieval Drang nach Osten with Haushofer's Lebensraum theories and to a substantial erasing of history. But we can say that Slavic, Teutonic, Hanseatic, Jagellonian, Vasa, Prussian and Polish Danzig/Gdansk are all contained in the contemporary city, highlighting the Hanse's positive influence given by the network of stable communications between Eastern, Western and Northern Europe, based on a spirit of dialogue and compromise against warfare, which made technological and cultural development possible for very remote areas.

Especially about the worries (affecting the debate on EU macro regions) on the heterogeneity of the national, socioeconomic situations, culture, political background, planning traditions and seniority as EU Member States, it is to be underlined that it was for only fifty years that the Countries of the Baltic Sea Macro Region were separated and isolated by the "Iron Curtain" and how the EU Strategy, in a certain sense, has allowed the re-emerging of deeply rooted historical links, leading back to the Vikings and the Hanseatic Period (the latter running from the XII to the beginning of the XVI century).

This means that, according to Faludi $(2010 a, b)$ we can say that geography (and history!) still matters and, therefore, place-based strategies are still needed: following Williams (1996), «spatial positioning» is still one of the key concepts to be considered, even though intended according to the contemporary meanings of "space", "place" and "territory" - as geographic, historic or symbolic shared "images", which may be seen as a precondition for the development of innovative (imaginative) solutions. 


\section{Conclusions: the Baltic Sea Strategy in Perspective}

It is too early to speak about the future of the Baltic Sea Strategy (BSS) and its implications on the economic, social and territorial cohesion of the region (and whether it fulfils the implementation of the Lisbon and Gothenburg Agendas, and not least the Territorial Agenda). What is already clear, is that the European Union will develop more of these "place-based" macro-regional strategies and approaches as «a tool of European integration and increased territorial cohesion» (Dubois et al, 2009). The elaboration of MRS makes it possible to promote the territorial dimension of EU policies and co-operation, because «the benefits of defining more "localised" policies are beyond dispute» (Salez, 2009).

Certainly, a one-size-fits-all approach does not work in a European Union of 27 Member States and 271 regions, but the question is whether it is possible to cover the whole European territory with this kind of macro-regional policies.

The reason for this increased interest is due to the awareness that all regions are different, and - as pointed out by the Territorial Agenda and the Green Paper on Territorial Cohesion - these differences should be turned into strengths. It is impossible to compare one region with another as the prerequisites are diverse, just like the opportunities and feasibilities. With a MRS the coordination of collaboration and financial means is facilitated by sharing the common challenges, goals and accomplishments. There will always be some features that cannot be solved only on local, regional or national levels, but which have to be faced with a transnational approach (such as transport corridors, energy and ICT networks, environmental issues and problems inflicted by climate change).

The debate whether the MRS is to be considered as part of the Cohesion Policy, or as independent beings with a more integrated and place-based policy approach, induces the BSS, according to Samecki (2009), to be summarised as an opportunity for transnational co-operation to constitute an excellent laboratory for multi-level governance on common development challenges and opportunities, and a means for an integrated and co-ordinated implementation of multi-sectoral EU policies, aiming at increased economic, social and territorial cohesion. In other words: the MRS is a new way of making Europe more effective.

There have been some criticisms of the BSS as well. According to Peter Schmitt (2010), the BSS is indeed a place-based strategy but it «suffers from a comprehensive territorial perspective». He states that the VASAB Long Term Perspective could «serve as a complement and explicit territorial strategy that takes into account the function and problems of different types of territories within the Baltic Sea Region». Peter Schmitt argues (and fears) that a macro-regional strategy, even if it is placebased, is not so clearly linked to territorial cohesion that it should be, because generally the latter focuses on better economic performance of different types of territories/regions, thus he sees a need for a co-ordination between the actions/policies and the location of the territory that they are supposed to have an impact on (Schmitt, 2010).

On the other hand, Faludi (2010a) argues that, if spatial planning is to be formulated as macro-regional strategies, then it becomes a vehicle, both for territorial cohesion and EU policymaking in general. If so, the interest in spatial planning is certain to increase.

Furthermore, understanding macro-region as "synaptic spaces" could allow us to imagine Europe in terms of cities, urban-systems, city-borne regions, and macro-regions: a more heterogeneous, complex and well-defined and coherent organism (in the biological sense), defined by deeper cultural layers (rather than those imposed by modern states).

\section{References}

[1] Albrechts, L., Alden J. and Da Rosa Pires A. eds., 2001. The Changing Institutional Landscape of Planning. Aldershot: Ashgate.

[2] Altshuler, A., Morrill, W., Wolman, H. and Mitchell, F. eds., 1999. Governance and Opportunity in America. Washington, DC: National Academy Press.

[3] Anderson, P., 1999. Complexity Theory and Organization Science. Organization Science, 10(3).

[4] Atlan, H., 1983. L'emergence du noveau et du sens. In: P. Dumouchel and J.P. Dupuy eds. L'Auto-organisation. De la physique au politique. Colloque de Cerisy. Paris: Seuil.

[5] Bache, I. and Flinders, M. eds., 2005. Multi-level Governance. Oxford: Oxford University Press.

[6] Bachelard, G., 1957. La poétique de l'espace. Paris: Presses Universitaires de France.

[7] Backzo, B., 1978. Lumiéres de l'utopie.. Paris: Payot.

[8] Bak, P., 1996. How Nature Works: The Science of SelfOrganized Criticality. New York: Copernicus.

[9] Berezin, M., 2003. Introduction: territory, emotion and identity: spatial recalibration in a new Europe. In: M. Berezin, and M. Schain, eds. Europe Without Borders: Remapping Territory, Citizenship and Identity in a Transnational Age. Baltimore: Johns Hopkins University Press.

[10] Borges, J.L., 1952. Otras inquisiciones. Buenos Aires: Sur.

[11] Brenner, N., 2003. Metropolitan Institutional Reform and the Rescaling of Space in Contemporary Western Europe. European Urban and Regional Studies, 10(4), pp. 297-324.

[12] Brenner, N., 2009. A Thousand Leaves: Notes on the Geography of Uneven Spatial Development. In: R. Keil and R. Mahon, eds. Leviathan Undone? Towards a Political Economy of Scale. Vancouver: UBC Press.

[13] Brown, T.L., 2003. Making truth: metaphor in science. Urbana: University of Illinois Press. 
[14] Castells, M. 1996. The Rise of the Network Society. Cambridge, MA: Blackwell.

[15] Castells, M. 2001. The Internet Galaxy. Oxford: Oxford University Press.

[16] CEC-Commission Of The European Communities, 2009. Communication from the Commission to the European Parliament, the Council, the European Economic and Social Committee and the Committee of the Regions concerning the European Union Strategy for the Baltic Sea Region. Brussels, 10.6.2009, COM(2009) 248 final.

[17] Cremaschi, M., 2004. The 'light' Europeization of spatial development policies, lecture at the University Centre for International Studies, University of Pittsburgh, February 2004.

[18] D'Haenens, A. ed., 1984. Europe of the North Sea and the Baltic. The world of Hanse. Anvers: Mercator.

[19] Davoudi, S., 2003. Polycentricity in European Spatial Planning: From an Analytical Tool to a Normative Agenda. European Planning Studies, 11, pp. 979-999.

[20] Davoudi, S., 2005. The Northern Way: a polycentric megalopolism. Yorkshire and Humberside Regional Review, 15,1 .

[21] Delanty, G. and Rumford, C., 2006. Political globalization. In: G. Ritzer, ed., Blackwell Companion to Globalization. Oxford: Blackwell.

[22] Dijst, M, Schenkel, W. and Thomas, I. eds., 2002. Governing Cities on the Move: Functional and Management Perspectives on Transformations of European Urban Infrastructure. Aldershot: Ashgate.

[23] Dollinger, P., 1964. Le Hanse. Paris: Aubier.

[24] Dubois, A., Hedin, S., Schmitt, P. and Sterling, J., 2009. EU macro-regions and macro-regional strategies - A scoping study. Stockholm: Nordregio.

[25] Faludi, A., 1996. Framing with Images. Environment and Planning B: Planning and Design, 23.

[26] Faludi, A., 2007. Making Sense of the Territorial Agenda of the European Union. European Journal of Spatial Development, 25.

[27] Faludi, A., 2008. European Territorial Cooperation and Learning. disP, 172, 1.

[28] Faludi, A., 2009. A turning point in the development of European spatial planning? The 'Territorial Agenda of the European Union' and the 'First Action Programme'. Progress in Planning, 71, pp. 1-42.

[29] Faludi, A., 2010a. European Spatial Planning: past, present, future. Town Planning Review, 81(1), pp.1-22.

[30] Faludi, A., 2010b. Beyond Lisbon: Soft European Spatial Planning. disP, 182.

[31] Fleck, L., 1980. Enstehung und Entwicklung einer wissenshaftlichen Tatsache. Frankfurt: Suhrkamp.

[32] Fritze, K., 1984. The Hanse and Marxist historiography. In: A. D'Haenens, ed., Europe of the North Sea and the Baltic. The world of Hanse. Anvers: Mercator.
[33] Gabellini, P., 1996. Il disegno del piano. Roma: NIS - La Nuova Italia Scientifica.

[34] Gramsci, A., 1977. Quaderni dal carcere. Torino: Einaudi.

[35] Granovetter, M., 1983. The strength of the weak ties: a network theory revisited. Sociological theory, 1.

[36] Gruber, H.E., 1966. Pensée créatrice et vitesse du changement adaptif: le développement de la pensée de Darwin. In: H.E. Gruber, Psychologie et épistemologie génetiques. Thèmes piagé tiens. Paris: Dunod.

[37] Gualini, E. and Woltjer, J., 2004. The Rescaling of Regional Planning and Governance in the Netherlands. Paper presented at the AESOP annual conference, Grenoble.

[38] Hambleton, R., 2003. The New City Government: Innovation, Service and Democratic Renewal. Occasional Paper, 5, Brown Institute of Public Affairs, UCLA.

[39] Haughton, G., Allmendinger, Ph., Counsell, D. and Vigar, G., 2010. The New Spatial Planning: Territorial Management with Soft Spaces and Fuzzy Boundaries. London: Routledge.

[40] Healey, P., 1998. Building Institutional Capacity Through Collaborative Approaches to Urban Planning. Environment and Planning A, 30(9).

[41] Healey, P., 2003a. Network Complexity and the Spatial Imaginative Power of Strategic Spatial Planning. Paper presented at the joint AESOP/ACSP Congress, Leuven, July 2003.

[42] Healey, P., 2003b. Creativity, Governance and the Public Sphere. Paper presented at the conference "Cities, urbanity and urban interventions”, Brussels, February 2003.

[43] Hirschorn, L., 1980. Scenario Writing: A Developmental Approach. Journal of the American Panning Association, 46.

[44] Hobsbawm, E.J. and Ranger, T.O., 1983. The Invention of Tradition. Cambridge-New York: Cambridge University Press.

[45] Holland, J.H., 1995. Hidden Order: How Adaptation Builds Complexity. Reading, MA: Addison-Wesley.

[46] Holling, C.S., 1973. Resilience and stability of ecological systems. Laxenburg: International Institute for Applied Systems Analysis.

[47] Holton, G., 1978. The Scientific Imagination. Cambridge: Cambridge University Press.

[48] Jachtenfuchs, M. and Kohler-Koch, B., 2004. Governance and institutional development. In: A. Wiener and T. Diez eds., European Integration Theory. Oxford: Oxford University Press.

[49] Jouvenel, B., 1964. L'art de la conjecture, Futuribles. Monaco: Ed. Du Rocher.

[50] Katz, B. ed., 2000. Reflections on Regionalism. Washington, DC: Brookings Institution Press.

[51] Kauffman, S.A., 1995. At home in the Universe: The Search for Laws of Self-Organization and Complexity. New York: Oxford University Press.

[52] Keil, R. and Mahon, R. eds., 2009. Leviathan Undone? Towards a Political Economy of Scale. Vancouver: UBC Press. 
[53] Kuhn, T.S., 1962. The structure of scientific revolutions. Chicago: University of Chicago Press.

[54] Le Galès, P., 1998. Regulation and Governance in British Sites. International Journal of Urban and Regional Research, 22(3), pp. 482-506.

[55] Magnusson, W., 2009. Scaling Government to Politics. In: R. Keil and R. Mahon eds., Leviathan Undone? Towards a Political Economy of Scale. Vancouver: UBC Press.

[56] March, J.G. and Olsen, J.P., 1995. Democratic Governance. New York: Free Press.

[57] Marks, G., Scharpf, F., Schmitter, P. and Streek, W., 1996. Governance in the European Union. London: Sage.

[58] Miller, B., 2009. Is Scale a Chaotic Concept? Notes on Processes of Scale Production. In: R. Keil and R. Mahon eds., Leviathan Undone? Towards a Political Economy of Scale. Vancouver: UBC Press.

[59] Mills, C.W., 1959. The Sociological Imagination. New York: Oxford University Press.

[60] Morin, E., 1977. La Méthode, t.I: La nature de la nature. Paris: Seuil.

[61] Palermo, P.C., 1998. L'autonomia del progetto e il problema della 'visione condivisa'. Urbanistica, 110.

[62] Patlagean, E., 1978. Histoire de l'imaginaire. In: J. Le Goff ed., La nouvelle histoire. Paris: Retz.

[63] Prigogine, I. and Stengers, I., 1979. La nouvelle alliance. Paris: Gallimard.

[64] Rein, M. and Schön, D., 1986. Frame-reflective policy discourse. Beleidsanalyse, 15(4).

[65] Sabel, C.F. and Zeitlin, J. eds., 2010. Experimentalist Governance in the European Union Towards a New Architecture. Oxford: Oxford University Press.

[66] Salet, W., 2003. Rescaling of territorial governance: Recent experiences in Dutch urbanised regions. Paper presented at the international workshop "Territorial governance in a multi-level environment: new forms of institutional action", University of Amsterdam, 14-15 November 2003.

[67] Salet, W. and Faludi, A. eds., 2000. The Revival of Strategic Spatial Planning. Amsterdam: Royal Netherlands Academy of Arts and Sciences.

[68] Salet, W., Thornley, A. and Kreukels, A. eds., 2003. Metropolitan Governance and Spatial Planning: Comparative Case Studies of European City-Regions. London: SPON Press.

[69] Salez, P., 2009. How EU comes into Spatial Planning: from the birth of regional policy to the Green paper on territorial cohesion, the emergence of the Community as a player over more than 20 years. Downloadable at: http://www.euterritorial-

agenda.eu/Related\%20Documents/livre\%20geographie $\% 20$ 2009\%20texte\%20bis\%20EN.pdf .

[70] Samecki, P., 2009. Speech at the Ministerial Conference on the EU Baltic Sea Strategy, 18 of September 2009, Stockholm. Downloadable at: http://www.eumonitor.net/modules.php?op=modload\&name $=$ News $\&$ file $=$ article $\&$ sid $=135429 \&$ mode $=$ thread\&order $=0 \&$ thold $=0$.

[71] Sartre, J.P., 1936. L'imagination. Paris: Presses Universitaires de France.

[72] Sartre, J.P., 1940. L'immaginaire. Psycologie phénoménologique de l'imagination. Paris: Gallimard.

[73] Sassen, S., 2001. The Global City. Princeton: Princeton University Press (2nd edition).

[74] Scharpf, F.W., ed., 1993. Games in Hierarchies and Networks. Analytical and Empirical Approaches to the Study of Governance Institutions. Frankfurt am Main: Westview Press.

[75] Schildhauer, J., 1988. The Hansa: History and Culture. New York: Dorset.

[76] Schmitt, P., 2010. A Baltic Sea Strategy beyond 2013. Presentation at CoR's Forum "Europe's macro-regions. Integration through territorial co-operation", Brussels, $13^{\text {th }}$ April 2010, downloadable at: http://www.cor.europa.eu/pages/EventTemplate.aspx?view= folder\&id=177a95fc-ce27-4d76-82ce$457420963 \mathrm{ce} 4 \& \mathrm{sm}=177 \mathrm{a} 95 \mathrm{fc}-\mathrm{ce} 27-4 \mathrm{~d} 76-82 \mathrm{ce}-$ 457420963 ce 4 .

[77] Scholte, J.A., 2004. Globalization and governance: from statism to polycentricity. GSGR Working Paper, 130/04 http://www.csgr.org .

[78] Scott, A.J., 2001. Global city-regions: Trends, theory, policy. Oxford: Oxford University Press.

[79] Secchi, B., 1984. Il racconto urbanistico. Torino: Einaudi. Secchi, B., 1988. Codificare, Ridurre, Banalizzare. Urbanistica, 91.

[80] Secchi, B., 1989. Un progetto per l'urbanistica. Torino: Einaudi.

[81] Soubeyran, O., 1988. Vingt and déja: un retour à la case dé part?. Cahiers de Géographir du Québec, 87.

[82] Starobinsky, J., 1970. Jalons pour une histoire du concept d'imagination. In: J. Starobinsky, La relation critique. Paris: Gallimard.

[83] Stead, D., 2011. Policy \& Planning Brief. Planning Theory \& Practice, 12(1), 163-167.

[84] Storper, M., 1997. The Regional World. New York: Guilford Press.

[85] Van Foester, H., 1981. Observing systems. Seaside: Intersystem Publications.

[86] Vigar, G., Healey, P., Hull, A. and Davoudi, S., 2000. Planning, Governance and Spatial Strategy in Britain: An Institutionalist Analysis. London: Palgrave MacMillan.

[87] Waldrop, M., 1992. Complexity: The Emerging Science at the Edge of Order and Chaos. New York: Simon and Schuster.

[88] Waterhout, B., 2008. The Institutionalisation of European Spatial Planning. PhD Dissertation, Delft University of Technology, Delft University Press.

[89] Waterhout, B., 2009. Soft spatial planning - what, why and how?. Unpublished workshop paper. 
[90] Weick, K., 1976. Educational Organizations as Loosely Couplet Systems. Administrative Science Quarterly, 21.

[91] Williams, R.H., 1996. European Union Spatial Policy and Planning. London: Chapman Publishing.
[92] World Bank, 2003. World Development Report: Sustainable Development in a Dynamic World. Oxford: Oxford University Press. 